ENTREPRENEURSHIP AND SUSTAINABILITY ISSUES

ISSN 2345-0282 (online) http://jssidoi.org/jesi/

2020 Volume 7 Number 3 (March)

http://doi.org/10.9770/jesi.2020.7.3(47)

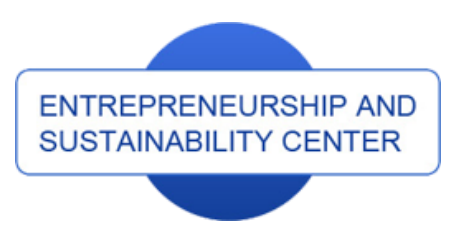

Publisher

http://jssidoi.org/esc/home

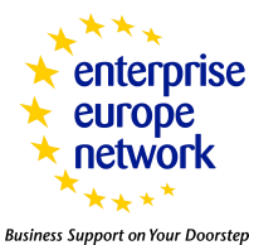

CASPA

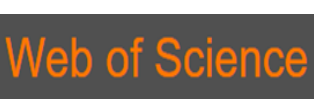

1 Clarivate

Analytics

\title{
CORPORATE SOCIAL RESPONSIBILITY OF BUSINESS AS A FACTOR OF REGIONAL
} DEVELOPMENT

\author{
Olga Yu. Voronkova ${ }^{1 *}$, Margarita V. Melnik ${ }^{2}$, Yulia V. Nikitochkina ${ }^{3}$, Nadezhda M. Tchuykova ${ }^{4}$, \\ Alla A. Davidyants ${ }^{5}$, Svetlana V. Titova ${ }^{6}$ \\ 1*Altai State University, Lenin Ave., 61, 656049, Barnaul, Russian Federation \\ ${ }^{2}$ Financial University under the Government of the Russian Federation, Leningradsky Prospekt, 49, 125993, Moscow, \\ Russian Federation \\ ${ }^{3}$ Financial University under the Government of the Russian Federation, Lenin gradsky Prospekt, 49, 125993, Moscow, \\ Russian Federation \\ ${ }^{4}$ Plekhanov Russian University of Economics, Stremyanny lane, 36, 117997, Moscow, Russian Federation \\ ${ }^{5}$ Sechenov First Moscow State Medical University, 119991, Moscow, Trubetskaya st., 8-2, Russian Federation \\ ${ }^{6}$ Kazan Innovative University named after V.G. Timiryasov, Moskovskaya st., 42, Kazan, Russian Federation
}

$$
\text { E-mails: *1 olka2004@yandex.ru (Corresponding author) }
$$

Received 14 March 2019; accepted 30 September 2019; published 15 March 2020

\begin{abstract}
The business community plays an essential role in ensuring sustainable regional development. This is due both to the powerful financial potential of business, which is particularly important with limited state budgetary resources, and to the high scientific and technical potential of companies, which is essential for maintaining their international competitiveness. The contribution of business to social development and sustainable regional development will depend, first, on the growth in traditional activities and the creation of new projects, and second, on the modernization of existing industries for reducing the negative impact on the region's environment and population. In recent decades, the concept of social responsibility of business, that is, its responsibility to the population or society has been developed by the most conscious and forward-looking part of the Russian business community, which has initiated impressive voluntary activity in this field. This relates essentially to large private or state-owned businesses. The business community is actively engaged with interested business and social groups, implementing contemporary international standards of socially oriented and environmental management, publishing social reports, including in the field of sustainable regional development.
\end{abstract}

Keywords: sustainable development; business entities; social responsibility; regional development

Reference to this paper should be made as follows: Voronkova, O.Y., Melnik, M.V., Nikitochkina, Y.V., Tchuykova, N.M., Davidyants, A.A. Titova, S.V. 2020. Corporate social responsibility of business as a factor of regional development. Entrepreneurship and Sustainability Issues, 7(3), 2170-2180. https://doi.org/10.9770/jesi.2020.7.3(47)

JEL Classifications: Q01, I30, J59 


\section{Introduction}

The development of corporate social responsibility in Russia remains inadequate and noncompliant with international standards and does not actually cover small and medium-sized businesses. The point is that social responsibility, presented to society in an open form, means the activities of enterprises in three "zones" of responsibility and sustainable development: economic (quality and safety of products and services, their physical and price availability), environmental (reduction of harmful emissions and other environmental pressures) and social (development of the in-house teams and external social projects, including charitable ones) (Kuznetsova et al., 2019; Akhmetshin et al., 2018; Frolova et al., 2017). As a rule, Russian small and medium-sized businesses are limited to local charity (Fedulova et al., 2019; Dunets et al., 2019; Ishchenko and Magsumov, 2019), presenting it as the dominant form of their social responsibility.

In Russia, in addition to extremely poor involvement of small and medium-sized businesses in this process, there is no progressive development in this area among large state and partially state-owned enterprises. This is largely due to the lack of transparency in doing business in Russia. Thus, open publication of social and environmental reports or reports on sustainable development under international standards requires additional voluntary disclosure of important data in all areas of business activity. As many studies have shown, the transparency level of Russian state-owned businesses is much lower compared to private businesses, which, of course, cannot be considered normal (Dynkin et al., 2018; Tadeu et al., 2019; Demchenko et al., 2019; Porokhin et al., 2014). In theory, everything should be exactly the opposite: after all, state-owned companies inherently should be more open to society and more socially responsible.

\section{Methods}

The research is based on the study of corporate social responsibility of the business community as an essential factor in the sustainable regional development, the formation of organizational and economic relations between subjects of sustainable development, in particular, through the mechanism of social partnership. The works of Russian and foreign scientists, scientific reports and recommendations, laws, decrees of the President, orders of the Government of the Russian Federation, regulatory documents of the constituent entities of the Russian Federation, the regulatory framework of foreign countries served as a theoretical basis for the study. The methodological basis was a systematic approach that ensured the complexity, consistency, and focus of the study. The authors applied analytical, abstract-logical, computational-constructive, economic-statistical, monographic and other research methods.

\section{Results}

For nearly three decades, developed and developing countries have been paying increased attention to corporate social responsibility (Campbell, 2007; Folke, 2006; Moon, 2002; Ermakova et al., 2016; Salamon, 1987; Aktan et al., 2018; Tvaronavičienè, 2018; Moumen et al., 2019; Rezk et al., 2019).

The most notable initiatives in this area have been put forward during this period. Those include the United Nations Environment Program (UNEP) Financial Initiative, which brings together more than 200 leading and largest global banks and investment companies, has been operational for twenty years and aims to ensure their compliance with the principles of socially and environmentally responsible financing and investment. The International Extractive Industries Transparency Initiative, launched in 2002 at the Johannesburg Summit on Sustainable Development, is becoming increasingly important. It aims to ensure the transparency of private and state revenues and payments in the mining sector, combining the largest resource-extracting and processing companies and governments of many 


\section{ENTREPRENEURSHIP AND SUSTAINABILITY ISSUES}

ISSN 2345-0282 (online) http://jssidoi.org/jesi/

2020 Volume 7 Number 3 (March)

http://doi.org/10.9770/jesi.2020.7.3(47)

African and Latin American countries, which have recently been joined by Asian states: Azerbaijan, Kazakhstan, and Kyrgyzstan.

The global initiative for reporting on the sustainable development of enterprises of all sizes and types of activity is now fully operational. Today, thousands of leading world companies, including transnational ones, report under the international GRI standard. Those include about 50 Russian companies. Most international initiatives consider the sustainable development of enterprises as a central goal of corporate social responsibility in its three-dimensional dimension: economic, environmental and social. It is proved that steady production growth, inextricably linked to reducing environmental pressures and a corresponding increase in the social security of employed workers and social support for the regional population, is becoming the main ideology of the modern business community. In total, more than 10,000 leading global companies regularly report to the public on corporate social responsibility and sustainable development (Kitzmueller, 2010).

At the same time, the leaders of many large Russian companies are not satisfied with the term "corporate social responsibility". This is not accidental since the term "social" implies the company's responsibility to society as a whole, not limited to its investors, employees and customers, which does not always suit businessmen based on their understanding of the allocation of social responsibility in the broad sense. Enterprises pay taxes, and, accordingly, the state must correctly and efficiently use them for the benefit of society, that is, it is a function of the state, and not of companies as such. At the same time, enterprises do not deny their public responsibility, in particular in the field of production ecology, as well as in understanding their responsibility in the chain of suppliers and consumers of the products and services proposed. Therefore, many companies prefer to use a slightly different formula for its activities in this area, namely the "corporate civil responsibility" (Blagov, 2015; Andreev, 2014; Bobylev et al., 2017; Solodova et al., 2018; Tannady et al., 2019). This term reflects the voluntary nature of the civil behavior of enterprises that are responsible for the processes taking place in their business environment and society as a whole.

Recently, several Russian companies have moved away from the attitude "we produce the product that the consumer needs and pay taxes, this is our responsibility" to open civil responsibility, which is voluntary. There are two main reasons for this. First, the dependence of manufacturing companies on the social conditions of their activities in the regions of their presence is objectively increasing. Second, the reason motivating companies to invest in this "nonproductive sphere" is their awareness that consistent systematic implementation of corporate social responsibility allows introducing a non-financial risk management system, which is based on engagement with stakeholders.

These two main directions of change in the field of corporate social responsibility result in the consistent improvement of corporate governance, a significant increase in its level, which positively affects the image, business reputation and, ultimately, capitalization of enterprises. That is, in terms of operation, enterprises incur additional non-productive expenses, but ultimately benefit from an increase in their market value or capitalization. It is worth noticing that the capitalization rate significantly exceeds the growth of corporate social responsibility costs (Shatalova et al., 2015, 2016; Ivanova et al., 2019; Rahman et al., 2017).

It is understood that sustainable development is the main idea of the future in the 21 st century. This is reflected in the conceptual documents of the UN, including three most important documents: "The future we want" (2012), which defines the prospects for humanity in the 21st century in the concept of sustainable development, based on "green" economy; "The agenda for sustainable development up to 2030" (2015); Paris Climate Agreement (2015), which sets the priorities for combating the climate threat in the world and in all countries until 2030-2050 (Androniceanu, 2019). These UN documents successfully combine both conceptual priorities and specific objectives of the countries and peoples. These documents contain quantitative indicators and a set of measures that allow governments to plan their actions for the implementation of the decisions taken. As a result of complex work, the UN adopted 17 Goals and 169 tasks for their implementation. 
The goals and objectives in the field of sustainable development in its content are complex, global and universally applicable. At the same time, they allow for consideration of differences in national mentality, opportunities and levels of development, as well as imply the respect for the national strategies and priorities. The objectives were drafted in the form of global recommendations, while every government sets its national objectives, guided by global wishes, but considering national circumstances. Every society at the country level decides how to ensure that these global challenges are recognized in the form of recommendations in the national planning processes, measures and strategies.

Thus, the Russian government has limited to the list of 8 objectives, some of which were reformulated given the Russian specifics (Rogach et al., 2018). For example, the second UN Goal "Achieving universal primary education" was replaced by the goal "Ensuring accessibility of education". In the UN goal No. 6, malaria was replaced by tuberculosis, which is a more relevant disease for Russia (see Table 1).

Table 1. Millennium Development Goals (2000-2015) adapted for Russia

\begin{tabular}{|l|l|}
\hline \multicolumn{1}{|c|}{ No. } & \multicolumn{1}{|c|}{ Goal definition } \\
\hline 1 & Poverty reduction and hunger eradication \\
\hline 2 & Ensuring the accessibility of education \\
\hline 3 & Promoting gender equality and women's empowerment \\
\hline 4 & Reducing maternal mortality \\
\hline 5 & Reduction of under-five mortality \\
\hline 6 & Combating HIV/AIDS, tuberculosis and other diseases \\
\hline 7 & Ensuring environmental sustainability \\
\hline 8 & Participating in global cooperation that meets Russian national interests \\
\hline
\end{tabular}

Mankind has made significant progress in implementing the Millennium Development Goals (MDG); progress has been made for all goals and objectives. Thus, material welfare has increased across the globe, the hunger problem has softened. Due to the growth of the national economy and the well-being of its citizens in the early 2000s, Russia has achieved tangible progress in the main development goals - nominal cash incomes per capita for 2000-2015 had increased 13.3 times. During this period, life expectancy had increased by 6 years, including 4.4 years for women and 6.9 years for men. However, the 2014-2016 crisis revealed the instability of the Russian export-raw development model (Prodanova et al., 2019; Zubarevich, 2018; Takhumova et al., 2018; Luzina et al., 2019; Verevkin, 2010).

The country has witnessed intensified problems of human development. There is a vital need for new development paths with the priority given to the sustainability and development of human potential. The scope and ambitions of the new "2030 Agenda" of the global community have grown dramatically: the Sustainable Development Goals (SDG) contain more than doubled as compared to Millennium Development Goals (20002015) - it contains nearly 10 times more objectives and 5 times more indicators (Table 2). The time interval remained unchanged - 15 years, which makes it possible to monitor the program results within the political career of the legislatures who adopted the program. Shorter terms would not have given enough time to achieve results and would be too dependent on business and electoral cycles in the world's leading countries. Longer terms would not provide for the necessary concentration of efforts and could lead to the fact that new generations of politicians would set new tasks due to the significantly altered situation in the world. 
ENTREPRENEURSHIP AND SUSTAINABILITY ISSUES

ISSN 2345-0282 (online) http://jssidoi.org/jesi/

2020 Volume 7 Number 3 (March)

http://doi.org/10.9770/jesi.2020.7.3(47)

Table 2. Comparison of the Millennium Development Goals (2000-2015) and the Sustainable Development Goals (2015-2030) (according to the UN)

\begin{tabular}{|c|c|c|}
\hline Indicators & MDG(2000-2015) & SDG (2015-2030) \\
\hline Goals & 8 & 17 \\
\hline Objectives & 18 & 169 \\
\hline Indicators & 48 & 230 \\
\hline
\end{tabular}

In Russia, it makes sense to adjust the goals of sustainable development at the regulatory and program level. Thus, scientific, methodological, informative and financial support for adapting sustainable development goals is presented in the Federal Law No. 172 "On Strategic Planning in the Russian Federation", which defines criteria for achieving strategic goals and substantiates the priorities of state policy in the field of socio-economic development and national security. Strategic project documents developed within the framework of goals based on the sectoral and territorial principle at the federal level should be supplemented by regional program documents, which will contribute to the implementation of the Spatial Development Strategy of the Russian Federation and the socio-economic development strategy of the regions, provided for by the law "On Strategic Planning in the Russian Federation" (Vinichenko et al., 2016). The study revealed that achieving the country's sustainable development goals might not be feasible without including the business community in the process of social responsibility. The authors believe that the social responsibility of business is a system of ethical standards and values, as well as a consistent set of economic, environmental and social measures implemented by continuous systemic interaction with stakeholders aimed at reducing non-financial risks, permanent improvement of goodwill and business reputation, increasing capitalization and competitiveness of the company, in order to ensure its profitability and sustainable development (Korableva et al., 2018; Plaskova et al., 2019; Da Silva et al., 2019; Sharafutdinov et al., 2019; Mukhtarova et al., 2017).

The sustainable development of the company is a complex matrix process for the business, which covers all areas of its activity and all management functions to reduce risks and losses, as well as to increase its efficiency, environmental friendliness and social responsibility.

The social responsibility of Russian companies is determined by their status and voluntary actions in this direction, which are shown in Figure 1.

Regular payment of salaries to employees and promotion of their social protection

Full payment of all types of taxes by business entities

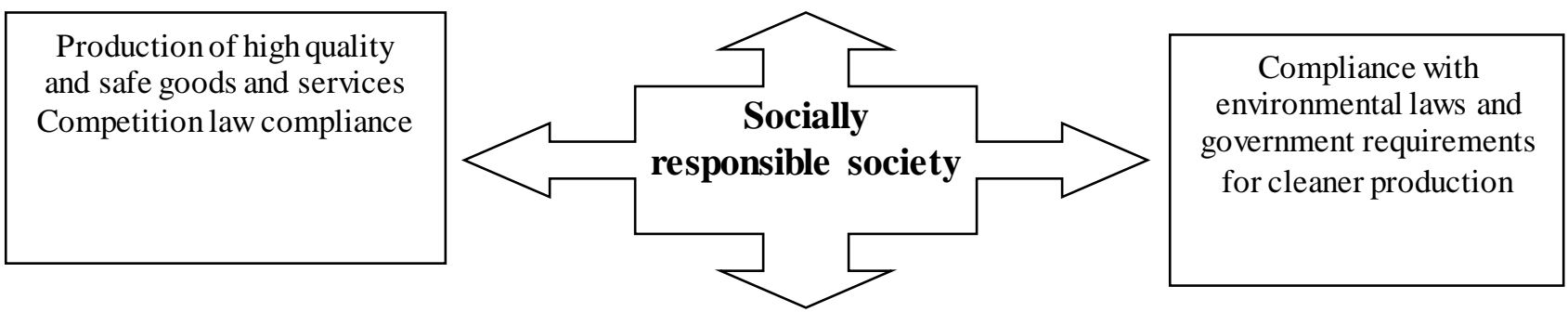

Ensuring labor protection, health and safety of employees, compliance with labor laws

Respect for human rights provided for by the Constitution of the Russian Federation

Fig. 1. The minimum set of corporate social responsibility indicators 


\section{ENTREPRENEURSHIP AND SUSTAINABILITY ISSUES}

ISSN 2345-0282 (online) http://jssidoi.org/jesi/

2020 Volume 7 Number 3 (March)

http://doi.org/10.9770/jesi.2020.7.3(47)

The authors believe that there is a tendency to shift social partnership towards the local community. This indicates that the interests of business structures are transferred from company employees to the external social environment. It can be concluded that the social interests of Russian businesses have also changed. In most companies, social policy is implemented based on principles approved by the highest executive body, corporate social programs are regular, and the funds for their implementation are included in the total budget. In 2014, the "Alliance Media" Russian business portal conducted an online survey of more than 1,500 entrepreneurs on social responsibility of business structures, which is highly relevant in Russia. The most common answers to the question "What actions do you attribute to the concept of social responsibility of the business community?" were: provision of employee benefits (32\%), creation of new jobs (31\%), assistance to social facilities (28\%) (Pavlov, 2019).

Following society's expectations, socially responsible Russian business can assume additional obligations that are part of a voluntary set of social responsibility indicators that are in the public interests, namely:

- to align the economy and corporate governance with the principles of social responsibility, enshrined in the Code of Corporate Conduct and Social Charter of Russian Business;

- to develop and consistently comply with internal codes or other documents of internal business ethics;

- to constantly develop quality, consumer properties and social significance of products and services;

- to maintain good business practice by establishing secure relationships with suppliers, distributors and customers, giving preference to those companies that meet the requirements of social responsibility;

- to support the development of small and medium-sized businesses, including internal technological chains, as well as to participate in relevant sectoral and intersectoral programs and funds;

- to take technological measures aimed at saving energy, water, and other resources;

- to organize the processing of industrial waste and wastewater treatment, gradually introducing non-waste production technologies;

- to control the emissions of substances that deplete the ozone layer, greenhouse gases, chemicals, and other harmonic emissions into the atmosphere;

- to ensure sustainable land use and support for biodiversity and natural habitats, including recreational areas and reserves;

- to ensure participation of social policy in social investments through internal and external social programs;

- to support personnel development and provide in-house training programs;

- to implement social projects of sponsorship and charitable nature in the territories of the company's presence, maintain their social well-being, safety, and sustainability;

- to participate in sponsorship and charity programs of regional and federal significance aimed at solving acute national problems;

- support social projects in culture, sports and education;

- to participate in public-private partnership projects aimed at solving social and environmental problems;

- to engage in the international charitable and social projects;

- to support public and non-profit organizations of civil society;

- regularly hold dialogues and public hearings with interested parties (stakeholders): shareholders and investors, employees and trade unions, suppliers and consumers, representatives of local, regional and federal state authorities, media, professional associations, public and non-profit organizations, etc. and thereby implement required changes to their activities;

- to increase business openness and transparency through regular social reporting and international reporting on sustainable development, thus improving the quality of production management, social development and non-financial risks. 


\section{ENTREPRENEURSHIP AND SUSTAINABILITY ISSUES}

ISSN 2345-0282 (online) http://jssidoi.org/jesi/

2020 Volume 7 Number 3 (March)

http://doi.org/10.9770/jesi.2020.7.3(47)

Additional indicators and measures in the field of business social responsibility are not restricted, being the subject of a voluntary civic initiative in cooperation with the company's stakeholders and society as a whole. Contributing to the effective management of non-financial risks, additional activities allow a company to demonstrate its moral responsibility for the state and development of society. Corporate social responsibility is a means of continuous and consistent increase in the competitiveness of Russian business, stimulating its technological and social innovativeness. In March 2013, the advisory GOST R ISO 26000:2012 "Guidance on social responsibility" came into effect, which is entirely based on ISO 26000:2010 $(12,2013)$. This standard is the first to define and disclose the concept of social responsibility of any company in accordance with the internationally accepted approaches. The standard provides a platform for integrated management of social responsibility in any company, outlining general principles and parameters of activities aimed at solving specific problems. This allows for developing and implementing a balanced strategy of social responsibility, increasing the effectiveness of interaction both within the company and with external stakeholders, as well as minimizing the risks associated with this interaction, based on internationally recognized approaches. Companies throughout the world and their stakeholders are increasingly aware of the need for socially responsible behavior and its benefits. At the same time, promoting sustainable development is the main goal of social responsibility.

The standard's structure and format conclusively demonstrate that the company's performance in relation to the society, in which it operates, and its environmental impact have become an extremely important part of assessing its overall performance and its ability to continue effective operation. This partly reflects the growing awareness of the need to maintain healthy ecosystems, social equity, and good organizational governance. In the long run, all company's activities depend on the well-being of global ecosystems (Yemelyanov et al., 2018). Companies are increasingly criticized by various stakeholders. The perception and reality of a company's performance in the field of social responsibility can influence, among other things:

- its competitive advantages;

- its reputation;

- its ability to attract and retain workers or members, customers, clients or users;

- maintaining its employees' morale welfare, engagement and productivity

- attitudes of investors, owners, donors, sponsors and the financial community; and its relationship with companies, governments, media, suppliers, peer organizations, customers and the local community.

GOST R ISO 26000: 2012 guides on the principles underlying social responsibility, recognition of social responsibility and stakeholder engagement, major topics and issues related to social responsibility (see table), and ways to integrate socially responsible behavior into the organization. This standard emphasizes the importance of results and improved performance in social responsibility.

All major topics apply to any organization. Each major topic incorporates several problems. Every company must decide which solution is applicable and most significant through independent analysis and dialogue with the interested parties.

All over the world, and Russia is no exception, the problems of non-financial risks play an increasingly strong role. They become increasingly important for investors, along with commercial, industrial and economic ones. Starting from about the mid-1990s, reporting on corporate social responsibility closes this "information gap" for the investor, showing and proving to him that this company pays constant attention to environmental and social aspects in its activities, thereby reducing the risks of social internal and external conflicts, as well as environmental sanctions (Hinzman et al., 2014; Movchan and Yakovleva, 2019; Razumova, 2017; Goryushkina et al., 2019). 


\section{ENTREPRENEURSHIP AND SUSTAINABILITY ISSUES}

ISSN 2345-0282 (online) http://jssidoi.org/jesi/

2020 Volume 7 Number 3 (March)

http://doi.org/10.9770/jesi.2020.7.3(47)

Under favorable circumstances, corporate social responsibility in the Russian Federation can become the basic ideology of corporate governance and management, as has already happened in many developed countries. In modern Russia, there is a whole palette of components of corporate social responsibility, and so far, each company provides its definition of this concept through the prism of its strategic objectives and priorities, its corporate culture and the degree of responsibility and obligations it is willing to assume.

\section{Conclusions}

Leading Russian socially responsible companies define several interrelated characteristics of their concept of social responsibility:

- Corporate social responsibility is a strategic business approach to managing the company's social, environmental and economic responsibility, which allows it to define and formulate a circle of obligations and areas of responsibility and implement them according to the principle of continuous improvement as part of the overall strategy for sustainable business development;

- $\quad$ Corporate social responsibility is a set of principles of conduct and management adopted by the company voluntarily and having a significant impact on the decision-making process at any level, based on a responsible attitude and incorporation of feedback from the parties that are strategically important for sustainable business development;

- $\quad$ Corporate social responsibility is a management system, which comprises a set of mechanisms and tools that allow managing coordinated and balanced non-financial aspects of the company.

This approach would encourage socially responsible companies to constantly and consistently implement this activity through regular dialogue with society and apply it in strategic planning and company management. Furthermore, it will also be reflected in the resulting system of economic, environmental and social indicators. The focus of this study is that any production and economic decisions are made in view of their social and environmental consequences for the company and society. In that framework, corporate social responsibility turns into a powerful factor in strategic development, strengthening the business reputation and the company's competitiveness.

In the Russian regions, as well as at the municipal level, there is a growing understanding of the need to build relations with business on a permanent and understandable basis. Whereas previously regional and local authorities turned to business mainly to urgently fill in "gaps" in social, environmental and economic infrastructure, today most of the governors, regional legislative assemblies, and city mayors prefer to plan joint medium-term projects and programs in various spheres. This is beneficial to both government and business. Stable partnerships are gradually built up. However, the planning for "sustainable regional development" is still far away. Of the known attempts, it is worth noticing only long-term development programs for the Tomsk Region and the city of Novosibirsk.

Corporate social responsibility is not a goal but a means to meet the urgent needs of people and society. The role of the state here is to "launch" this process in the right direction without overly administering the business by establishing clear requirements and rules, as well as economic and moral incentives, which shall not be changed annually, which too often happens with state regulation of the economy and environmental protection in Russia.

\section{References}

Akhmetshin, E. M., Pavlyuk, A. V., Hasanov, E. L., Sverdlikova, E. A., \& Kadyrov, M. A. (2018). Institutional mechanisms for implementation of entrepreneurial potential of the population of the region. Journal of Applied Economic Sciences, 13(7), $2052-2075$.

Aktan, B., Turen, S., Tvaronaviciene, M., Celik, S., Alsadeh, H.A. 2018. Corporate governance and performance of the financial firms in Bahrain. Polish Journal of Management Studies, 17(1), 39-58. https://doi.org/10.17512/pjms.2018.17.1.04 
ENTREPRENEURSHIP AND SUSTAINABILITY ISSUES

ISSN 2345-0282 (online) http://jssidoi.org/jesi/

2020 Volume 7 Number 3 (March)

http://doi.org/10.9770/jesi.2020.7.3(47)

Andreev, V. K. 2014. The nature of the corporate agreement. Prilozhenie Pravo i Biznes, 2, 2-6.

Androniceanu, A. 2019. The social sustainability of smart cities: urban technological innovation, big data management, and the cognitive internet of things. Geopolitics. History, and International Relations, 11(1), 110-115.

Blagov Yu. 2015. Corporate social responsibility: evolution of the concept. GSOM SPbU.

Bobylev S. N., Grigoriev L. M. 2017. Moscow Report on human development in the Russian Federation for 2016. Analytical center under the Government of the Russian Federation, 298.

Campbell, J. L. 2007. Why Would Corporations Behave in Social Responsible Way? An Institutional Theory of Corporate Social Responsibility. Academy of Management Review, 32(3), 946-967.

Da Silva, E. V. C., De Reis, I. F. A., Das De Almeida, L. N. T., Dos Prazeres, A. R., Da Silva, J. B., \& Do De Oliveira, A. C. S. (2019). Dehydrated apiculture pollen quality. Periodico Tche Quimica, 16(31), 335-340.

Demchenko, T.S.; Karácsony, P.; Vinichenko, M.V.; Demchenko, M.V.; Melnichuk, A.V. 2018. Youth involvement in social control of the implementation of the youth personnel policy in the company management system. Espacios, 38(21), 8.

Dynkin A., Telegina E., Khalova G. 2018. The role of Eurasian economic union in formation of Greater Eurasia. World economy and international relations, 4(62), 5-24.

Dunets, A., Muhamedieva, A., Sycheva, I., Perepechkina, E., Vakhrushev, I., \& Kulchytskiy, A. (2019). Spatial tourism planning: Using the model of functional and planning complexes. Journal of Environmental Management and Tourism, 10(4), 711-719. http://doi:10.14505/jemt.v10.4(36).01

Ermakova, A. N., Vaytsekhovskaya, S. S., Malitskaya, V. B., \& Prodanova, N. A. (2016). Investment attractiveness of small innovational business under the conditions of globalization and integration. European Research Studies Journal, 19(2) Special Issue), 258-267.

Fedulova, I., Ivanova, V., Atyukova, O., \& Nosov, V. (2019). Inclusive education as a basis for sustainable development of society. Journal of Social Studies Education Research, 10(3), 118-135.

Folke, C. 2006. Resilience: the emergence of a perspective for social-ecological systems analyses. Global Environmental Change, 15(3), 253-267.

Frolova, E.V., Medvedeva, N.V., Kabanova, E.E., Kurbakova, S.N., Vinichenko, M.V. 2016. Social Partnership in Russia: Prerequisites, Problems and Trends. Journal of Advanced Research in Law and Economics, 2(16), 221-228. https://doi.org/10.14505/jarle.v7.2(16).05

Goryushkina, N., Voinova, N., Voronkova, O., Sitnov, A., Shichiyakh, R., \& Gordeyeva, O. (2019). Theoretical aspects of entrepreneurial education for hospitality industry. Journal of Environmental Management and Tourism, 10(4), 835-841. https://doi:10.14505/jemt.10.4(36).14

Hinzman, L. D., Deal, C. J., McGuire, A. D., Mernild, S. H., Polyakov, I. Pachauri, R. K. \& Meyer, L. A. 2014. Climate Change 2014: Synthesis Report. Contribution of Working Groups I, II and III to the Fifth Assessment Report of the Intergovernmental Panel on Climate Change Core Writing Team. IPCC, Geneva, Switzerland, 151.

Yemelyanov, V., Yemelyanova, N., \& Nedelkin, A. (2018). Neural network for decision support to determine the operating mode of lined equipment. Paper presented at the MATEC Web of Conferences, $224 \mathrm{http}: / /$ doi:10.1051/matecconf/201822404005

International standard ISO 26000 "Guide to social responsibility". URL: http://www.ksovok.com/doc/isofdis26000rus

Ishchenko, O.V., \& Magsumov, T.A. (2019). Siberian Students' Material Situation in the early 20th century (based on Student Questionnaires). Bylye Gody, 51(1), 366-379.

Ivanova, T. S., Malarev, V. I., Kopteva, A. V., \& Koptev, V. Y. (2019). Development of a power transformer residual life diagnostic system based on fuzzy logic methods. Paper presented at the Journal of Physics: Conference Series, 1353(1) https://doi:10.1088/1742$\underline{6596 / 1353 / 1 / 012099}$

Kitzmueller M. 2010. Economics and Corporate Social Responsibility. Europen Review on Agricultural Economics, 788 p. 
ENTREPRENEURSHIP AND SUSTAINABILITY ISSUES

ISSN 2345-0282 (online) http://jssidoi.org/jesi/

2020 Volume 7 Number 3 (March)

http://doi.org/10.9770/jesi.2020.7.3(47)

Korableva, O. N., Kalimullina, O. V., \& Mityakova, V. N. (2018). Innovation activity data processing and aggregation based on ontological modelling. Paper presented at the 2018 4th International Conference on Information Management, ICIM 2018, 1-4. https://doi:10.1109/INFOMAN.2018.8392659

Kuznetsova, I. G., Surikov, Y. N., Votchel, L. M., Aleynikova, M. Y., Voronkova, O. Y., \& Shichiyakh, R. A. (2019). The methodological aspect of human capital formation in the digital economy. International Journal of Mechanical Engineering and Technology, 10(2), 10201030.

Luzina, T. V., Dudareva, E. A., Akhmetshin, E. M., Prodanova, N. A., Berdova, Y. S., \& Emaletdinova, G. E. (2019). International legal format for trans regionalisation of trade and economic partnership within BRICS in global development. Space and Culture, India, 7(3), 7685. https://doi:10.20896/saci.v7i3.508

Moon J. 2002. Business social responsibility and new governance. Government and Opposition, 37, 385-408.

Moumen, Z., El Idrissi, N. E., Tvaronavičienè, M. 2019. Water security and sustainable development. Insights into Regional De velopment, 1(4), 301-317. https://doi.org/10.9770/ird.2019.1.4(2)

Movchan, I. B., \& Yakovleva, A. A. (2019). Refined assessment of seismic microzonation with a priori data optimisation. Journal of Mining Institute, 236, 133-141. https://doi:10.31897/PMI.2019.2.133

Mukhtarova, K., Kupeshova, S., Ziyadin, S., \& Doszhan, R. (2017). Problems of developing the foundations of sustainable competitiveness of industrial and innovative economy in Kazakhstan. Economic Annals-XXI, 168(11-12), 38-43. https://doi:10.21003/ea.V168-08

Pavlov E. L. 2019. Corporate social responsibility as a promising tool for expanding the activities of international business. Economic relations, 9(4), 26-35.

Plaskova, N. S., Prodanova, N. A., Samusenko, A. S., Erzinkyan, E. A., Barmuta, K. A., \& Shichiyakh, R. A. (2019). Investment decisions formation: Innovative assets. International Journal of Engineering and Advanced Technology, 9(1), 2913-2916. https://doi:10.35940/ijeat.A1213.109119

Porokhin, A. V., Porokhina, E. V., Soina-Kutishcheva, Yu. N. \& Barylnikov, V. V. 2014. Sustainability as the defining characteristic of the state of social and economic system. Fundamental Research, 12(4), 816-821.

Prodanova, N. A., Trofimova, L. B., Bashina, O. E., Kachkova, O. E., Ilienkova, N. D., \& Polyanskaya, T. A. (2019). Approaches for obtaining audit evidence at fair value measurement. International Journal of Economics and Business Administration, 7(3), 279-292.

Rahman, P. A., Panchenko, A. A., \& Safarov, A. M. (2017). Using neural networks for prediction of air pollution index in industrial city. IOP Conference Series: Earth and Environmental Science, 87(4). https://doi.org/10.1088/1755-1315/87/4/042016

Razumova S. 2017. Concept of CSR: world experience and practice of Belarus companies. Scientific Forum: Economics and Management, (7), 22-29.

Rezk, M. R., Radwan, A., Salem, N. M., Sakr, M. M., Tvaronavičienè, M. 2019. Foresight for sustainable energy policy in Egypt: results from a Delphi survey. Insights into Regional Development, 1(4), 357-369. https://doi.org/10.9770/ird.2019.1.4(6)

Rogach, O.V.; Ryabova, T.M.; Frolova, E.V.; Evstratova, T.A.; Kozyrev, M.S. 2018. Social and psychological climate in state. Espacios, 39(11), 19.

Salamon, M.W. 1987. Industrial Relations: Theory and Practice, London: Prentice-Hall International, 580p.

Sharafutdinov, R., Gerasimov, V., Akhmetshin, E., Karasik, E., \& Kalimullina, O. (2019). Inclusive development index in Russia: analysis, methods, possibility of application. Revista Genero \& Direito, 8(4), Special Issue, 231-241.

Shatalova, T. N., Chebykina, M. V., Zhirnova, T. V., \& Bobkova, E. Y. (2016). Controlling system as a key factor energy management of an industrial enterprise. International Review of Management and Marketing, 6(1), 7-12.

Shatalova, T. N., Chebykina, M. V., Zhirnova, T. V., \& Bobkova, E. Y. (2015). Methodological problems in determining the basic features of the sample set controlling the activities of the enterprise. Mediterranean Journal of Social Sciences, 6(3S4), 261-268. https://doi.org/10.5901/mjss.2015.v6n3s4p261 
ENTREPRENEURSHIP AND SUSTAINABILITY ISSUES

ISSN 2345-0282 (online) http://jssidoi.org/jesi/

2020 Volume 7 Number 3 (March)

http://doi.org/10.9770/jesi.2020.7.3(47)

Solodova, E. P., Selyutina, A. V., Sharafutdinov, R. I., \& Kulmetev, R. I. (2018). Directions of small business development in housing and communal services of samara region. Paper presented at the Proceedings of the 31st International Business Information Management Association Conference, IBIMA 2018: Innovation Management and Education Excellence through Vision 2020, $3924-3930$.

Tadeu, P., Fernandez Batanero, J., \& Tarman, B. (2019). ICT in a Global World. Research in Social Sciences and Technology, 4(2), i-ii. Retrieved from https://ressat.org/index.php/ressat/article/view/431

Takhumova, O. V., Kasatkina, E. V., Maslihova, E. A., Yumashev, A. V., \& Yumasheva, M. V. (2018). The main directions of increasing the investment attractiveness of the Russian regions in the conditions of institutional transformations. Espacios, 39(37).

Verevkin L. 2010. Social responsibility of business. Monitoring of public opinion, 1, 44-55.

Tannady, H., Gunawan, E., Nurprihatin, F., \& Wilujeng, F. R. (2019). Process improvement to reduce waste in the biggest instant noodle manufacturing company in South East Asia. Journal of Applied Engineering Science, 17(2), 203-212.

Tvaronavičienè, M. 2018. Towards sustainable and secure development: energy efficiency peculiarities in transport sector. Journal of Security and Sustainability Issues, 7(4), 719-725. https://doi.org/10.9770/jssi.2018.7.4(9)

Vinichenko, M.V., Kirillov, A.V., Frolova, E.V., Kaurova, O.V., Makushkin, S.A. 2016. Monitoring of working conditions and the nature of their influence on health of students and academic staff. International Journal of Environmental and Science Education, 11(11): 45644577 .

World Employment and Social Outlook. 2015. The Changing Nature of Jobs, International Labour Organization. Retrieved from: https:/www.ilo.org/globa1/research/global-reports/weso/2015-changing-nature-of-jobs/lang--en/index.htm

Zubarevich N. 2019. Socio-economic development of Russian regions by 2020. Electronic resource / URL: http://russia2020.org/2010/08/23/soc-ec-development-of-rus-regions

Olga Yu. VORONKOVA

ORCID ID: https://orcid.org/0000-0002-3106-4643

Margarita V. MELNIK

ORCID ID: https://orcid.org/0000-0002-7428-9535

Yulia V. NIKITOCHKINA

ORCID ID: https://orcid.org/0000-0002-2558-4394

Nadezhda M. TCHUYKOVA

ORCID ID: https://orcid.org/0000-0001-6570-4787

Alla A. DA VIDYANTS

ORCID ID: https://orcid.org/0000-0002-5298-5767

Svetlana V. TITOVA

ORCHID ID: https://orcid.org/0000-0002-8419-2382

Copyright (C) 2020 by author(s) and VsI Entrepreneurship and Sustainability Center

This work is licensed under the Creative Commons Attribution International License (CC BY).

http://creativecommons.org/licenses/by/4.0/

(c) (i) Open Access 